\title{
Isolation, peroxisome proliferator-activated receptor-gamma transcription, glucose uptake, and molecular docking of tetramethoxyflavonoids from the leaves of Rourea mimosoides (Vahl) Planch
}

\author{
Che Puteh Osman ${ }^{1,2 *}$, Norhafizoh Abdul Somat ${ }^{1,2}$, Zuriati Zahari², Syahrul Imran ${ }^{1,2}$, Mohd Ilham Adenan ${ }^{3}$ \\ ${ }^{1}$ Atta-ur-Rahman Institute for Natural Product Discovery, Universiti Teknologi MARA Cawangan Selangor, Kampus Puncak Alam, 42300 Bandar Puncak \\ Alam, Selangor, Malaysia. \\ ${ }^{2}$ Fakulti Sains Gunaan, Universiti Teknologi MARA, 40450 Shah Alam, Selangor, Malaysia. \\ ${ }^{3}$ Fakulti Sainsi Gunaan, Universiti Teknologi MARA Cawangan Pahang, Kampus Jengka, 26400 Bandar Tun Razak, Jengka, Pahang, Malaysia.
}

\section{ARTICLE INFO \\ Received on: 30/11/2020 \\ Accepted on: 08/05/2021 \\ Available online: 05/08/2021}

\section{Key words:}

Connaraceae, cytotoxicity,

stigmast-4-one-3-ene,

rosiglitazone, diabetes.

\begin{abstract}
Rourea mimosoides (Vahl) Planch. is used traditionally to treat various diseases. The ethanolic leaves extract was found to increase the transcription of peroxisome proliferator-activated receptor-gamma (PPAR $\gamma$ ). Therefore, the present study is warranted to identify the active compounds from the dichloromethane and ethanolic leaves extract and examine their PPAR $\gamma$ binding and glucose uptake activity. The ground dried leaves were macerated successively in dichloromethane and ethanol and dried and fractionated using vacuum liquid chromatography. Exhaustive chromatographic procedures yielded to a new tetramethoxyflavonoid, quercetin tetramethyl ether-3-O- 3 -L-rhamnoside (1), along with a known quercetin tetramethyl ether (2) and a steroid (3). Compound 2 showed the highest PPAR $\gamma$ binding and glucose uptake activities at 0.313 and $2.5 \mu \mathrm{g} / \mathrm{ml}$, respectively. The leaves extract and compounds 1-3 showed no cytotoxicity when evaluated using HepG2 cells. Molecular docking result showed that compound $\mathbf{2}$ is able to interact with important residues within the hydrophobic pocket of the ligand-binding domain, thus acting as an agonist of PPAR $\gamma$.
\end{abstract}

\section{INTRODUCTION}

Rourea mimosoides (Vahl) Planch. belongs to the Connaraceae family. It is commonly known as "sembelit merah" (Grosvenor et al., 1995). The decoction of the root is traditionally used to treat bloody diarrhea, bloody cough, dysentery, and leprosy and as diuretics (Grosvenor et al., 1995), while the whole plant is used to treat colds in children and given to women after childbirth (Tan et al., 2013). To the best of authors' knowledge, no chemical compound is reported from $R$. mimosoides to date. Flavonoids, flavonoid glycosides, triterpenes, and phenolic acids

\section{*Corresponding Author}

Che Puteh Osman, Atta-ur-Rahman Institute for Natural Product Discovery, Universiti Teknologi MARA Cawangan Selangor, Kampus Puncak Alam, 42300 Bandar Puncak Alam, Selangor, Malaysia. E-mail: cheputeh@uitm.edu.my were previously reported in Rourea sp. (He et al., 2006; Kalegari et al., 2011; Laikowski et al., 2017; Oliveira et al., 2012; Zhang et al., 2008).

During our preliminary study, the ethanolic leaves extract of R. mimosoides was found to increase the transcription of the peroxisome proliferator-activated receptor-gamma (PPAR $\gamma$ ) gene. PPAR $\gamma$ agonists such as rosiglitazone and pioglitazone activate the transcription of target genes, which improve glucose homeostasis by systemic insulin sensitization or direct action PPAR- $\gamma$ on the transcription of genes involved in the glucose disposal (Rangwala and Lazar, 2004). PPAR $\gamma$ ligands improve insulin sensitivity, enhance insulin secretion, and improve glucose tolerance in diabetic patients (Janani and Ranjitha Kumari, 2015).

Molecular docking investigations on PPAR $\gamma$ transcription by natural products usually provide a detailed understanding of the ability of compounds to induce conformational changes on the cavity of the receptor upon binding (Pan et al., 2017). Some of the 
residues that play a vital role in the transcription activity include Arg288, Ser289, Glu343, and Tyr473, as indicated by the sitedirected mutagenesis approach (Mitro et al., 2013). Other binding interactions that are observed for transcription of PPAR $\gamma$ include the formation of the salt bridge to stabilize the PPAR $\gamma$ AF-2 helix, van der Waals interactions with residues I268, A272, N275, L309, I310, and F313 within the hydrophobic pocket, and electrostatic interactions with the side chain of residue R316 and backbone amide of A327 (Gampe et al., 2000).

Thus, the present study focuses on the identification of the active compounds from the leaves of $R$. mimosoides and the examination of their PPAR $\gamma$ binding and glucose uptake activity. The docking study of the active compound with PPAR $\gamma$ ligand is also illustrated.

\section{MATERIALS AND METHODS}

\section{General instrumentation}

Thin-layer chromatography was performed on the thin layer chromatography (TLC) silica gel $60 \mathrm{~F}_{254}$ aluminum sheets (1.05554, Merck, Germany) and visualized under ultraviolet light at 254 and $356 \mathrm{~nm}$. Preparative TLC was carried out using TLC silica gel $60 \mathrm{~F}_{254}$ glass plates (1.00390, Merck Germany). Column chromatography (CC) was performed using silica gel 60 (1.09385, 230-400 mesh, Merck, Germany). Vacuum liquid chromatography (VLC) was carried out using silica gel $60 \mathrm{PF}_{254}$ (1.07747, Merck, Germany). All the solvents used for extraction and isolation were of analytical grade. ${ }^{1} \mathrm{H}$ - and ${ }^{13} \mathrm{C}$-NMR spectra were acquired on a Bruker Ascend 600 (Switzerland) at 600 and $150 \mathrm{MHz}$, respectively, using $\mathrm{CDCl}_{3}$ or $\mathrm{CD}_{3} \mathrm{OD}$ as solvent. Chemical shifts were reported in ppm and $\delta$ scale with the coupling constants given in Hz. The mass spectra were recorded using LCMS/MS QTOF Agilent Technologies 6520 (Agilent, Santa Clara, CA). The UV absorbance for the in vitro analysis was obtained by Spectrostar Nanospectrometer (BMG Labtech, Ortenberg, Germany), while the 96-well plates were shaken on Scilogex SCI-M Microplate Mixer (Scilogex, US).

\section{Plant material}

Rourea mimosoides (Vahl) Planch. was collected in lowland and hill forest at elevation up to $750 \mathrm{~m}$ with latitude and longitude of $\mathrm{N} 05^{\circ} 33.654^{\prime}$, E $101^{\circ} 20.293^{\prime}$ of Royal Belum Rainforest in 2017. The plant was identified by Dr. Shamsul Khamis, a botanist from Universiti Kebangsaan Malaysia. The voucher specimen (IPH-423) was deposited at the Malaysian Institute of Pharmaceuticals and Nutraceuticals.

\section{Extraction and isolation}

The leaves (200 g) were air-dried, ground, macerated successively in $\mathrm{CH}_{2} \mathrm{Cl}_{2}$ (1 l) and EtOH (1 l l) for 48 hours, filtered, and dried under reduced pressure using Heidolph Rotavapor (Germany). The maceration was repeated two times for each solvent to give a total of 5 and $3 \mathrm{~g}$ of dichloromethane and ethanol extracts, respectively. $\mathrm{CH}_{2} \mathrm{Cl}_{2}$ extract $(5 \mathrm{~g})$ was subjected to fractionation using VLC eluted with $n$-hex-EtOAc-MeOH ( $n$-hex:EtOAc, 9:1 $\rightarrow$ 0:10; EtOAc:MeOH, 9:1 and 8:2) as elution system to give 63 fractions. Fractions $33-44(500 \mathrm{mg})$ were further purified using $\mathrm{CC}$ eluted with $\mathrm{CH}_{2} \mathrm{Cl}_{2}$ :EtOAc of increasing polarity $\left(\mathrm{CH}_{2} \mathrm{Cl}_{2}\right.$ :EtOAc, 10:0 $\rightarrow$ 0:10) to give 45 subfractions. Subfractions 4-15 (20 $\mathrm{mg})$ were pooled and subjected to preparative thin layer chromatography (PTLC), which yielded compound 2 (1 mg). Fraction $9(435 \mathrm{mg})$ was further fractionated using $\mathrm{CC}$ eluted with $n$-hex: $\mathrm{CH}_{2} \mathrm{Cl}_{2}\left(n\right.$-hex: $\left.\mathrm{CH}_{2} \mathrm{Cl}_{2}, 9: 1 \rightarrow 1: 9\right)$ to give 15 subfractions, of which purification of subfraction 5 (13.4 mg) using PTLC ( $n$-hex: $\left.\mathrm{CH}_{2} \mathrm{Cl}_{2}, 1: 9\right)$ afforded compound $3(5.1 \mathrm{mg})$. The fractionation of ethanolic extract $(3 \mathrm{~g})$ using $\mathrm{CC}$ eluted with $n$-hex-EtOAc-MeOH of increasing polarity ( $n$-hex:EtOAc, 9:1 $\rightarrow$ 1:9; EtOAc:MeOH, 9:1 and 8:2) afforded 73 fractions. Fraction $59(50 \mathrm{mg})$ was subjected to PTLC developed in $\mathrm{CH}_{2} \mathrm{Cl}_{2}: \mathrm{MeOH}(95: 5)$ to give compound $\mathbf{1}(2 \mathrm{mg})$.

Compound 1: quercetin tetramethyl ether 3-O-ß-Lrhamnoside (1) colorless crystals. HRESIMS m/z 505.2082 [M+H] $]^{+}$ (cald 504.4760 for $\mathrm{C}_{25} \mathrm{H}_{28} \mathrm{O}_{11}$ ). ${ }^{1} \mathrm{H}$ and ${ }^{13} \mathrm{C}$ NMR (see Table 1).

Compound 2: quercetin tetramethyl ether (2), light yellow crystals. HRESIMS $m / z$ 359.1578 $[\mathrm{M}+\mathrm{H}]^{+}$(cald 358.3374 for $\mathrm{C}_{19} \mathrm{H}_{18} \mathrm{O}_{7}$ ). ${ }^{1} \mathrm{H}$ and ${ }^{13} \mathrm{C}$ NMR (see Table 1 ).

\section{PPAR gamma assay}

PPAR gamma assay was carried out based on a previously reported study with slight modifications (Christensen et al., 2010). HepG2 (ATCC HB-8055) cell lines were obtained from the Department of Pharmaceutical Pharmacology \& Chemistry, Faculty of Pharmacy, Universiti Teknologi MARA. The cells were seeded in a 96-well plate (clear bottom) at a cell density of $8 \times 10^{4}$ cell/ml and incubated in an incubator supplemented with $5 \%(\mathrm{v} / \mathrm{v})$ $\mathrm{CO}_{2}$. Cells were then transfected using FuGENE ${ }^{\circledR} \mathrm{HD}$ transfection reagent (Promega Corporation, Madison, WI) according to the manufacturer's recommendation. In brief, the transfection reagent was mixed with OptiMEM (Invitrogen Corporation, Carlsbad) and later added to the plasmid composition of pSV-Sport PPAR $\gamma$, pACOX peroxisome proliferator response element (PPRE) $\times 3$, pSV-Sport retinoid X-receptor $(\mathrm{RXR}) \alpha$, and pRL-CMV. Transfecting cells were incubated for another 24 hours and treated with the compounds, concentration ranging from 20 to $0.039 \mu \mathrm{g} /$ $\mathrm{ml}$. These concentrations were used to evaluate the best binding activity of PPAR $\gamma$ exhibited by the compounds and compared to the positive control, rosiglitazone, which gave its best binding activity at $1 \mu \mathrm{M}$ (Christensen et al., 2010). Final concentration of DMSO was $0.5 \%(v / v)$ in all wells. Cells were incubated for the next 24 hours. Assay reagent from Dual-Glo Luciferase Assay System (Promega Corporation, Madison, WI) was added. The luminescence intensity produced through gene expression was measured using a luminometer (Promega, Madison, WI). The fold change of the luciferase ratio was calculated.

\section{Glucose uptake assay}

Glucose uptake assay was performed as described previously (Tedong et al., 2010), with few modifications. Myoblast cells (C2C12 and ATCC CRL-1772) were obtained from the Malaysian Institute of Pharmaceutical \& Nutraceuticals (IPharm). The cells were plated in 96-well plates (black and clear bottom) at a cell density of $8 \times 10^{4}$ cell $/ \mathrm{ml}$ and incubated in an incubator supplemented with $5 \%(v / v) \mathrm{CO}_{2}$ at $37^{\circ} \mathrm{C}$ for overnight to allow cell attached. The next day, cells were differentiated with differentiation medium including Dulbecco's Modified Eagle's Medium (Sigma-Aldrich, Germany), supplemented with 2\% 
$(v / v)$ of Horse Serum (Sigma-Aldrich, Germany) and 1\% ( $v / v)$ of $1,000 \mu \mathrm{g} / \mathrm{ml}$ of penicillin/streptomycin (Nacalai Tesque), and followed by incubation for 5-8 days. During this process, cells were differentiated at least $85 \%$ from myoblasts to myotubes. Differentiated myoblast was then treated with compounds, with concentrations ranging from 20 to $0.039 \mu \mathrm{g} / \mathrm{ml}$ and incubated for 24 hours. These concentrations were used to determine the efficacy of the compounds in the stimulation of glucose uptake and compared to the positive control, insulin with slight modification on maximal concentration, $200 \mu \mathrm{M}$ (Anandharajan et al., 2006). Cells were then washed and lysed using a buffer. Cell lysates were transferred into a 96-well plate (clear bottom) and were analyzed for relative fluorescence units using a microplate reader at 465/540 $\mathrm{nm}$ (Tecan, Morrisville, NC). The fold increase in glucose uptake activity was calculated.

\section{Cytotoxicity assay}

Cytotoxicity assay was performed on both HepG2 and $\mathrm{C} 2 \mathrm{C} 12$ differentiated cells based on the previously reported protocol (Alwi et al., 2019). Briefly, 150,000 cells $/ \mathrm{ml}$ were plated into the 96-well plates (clear bottom) and incubated in an incubator supplemented with $5 \%(v / v) \mathrm{CO}_{2}$ at $37^{\circ} \mathrm{C}$ overnight to allow cells to be attached. The next day, cells exposed to compounds with concentration ranged from 100 to $1.5625 \mu \mathrm{g} / \mathrm{ml}$ and incubated for 24 hours. The ranges of concentrations were chosen to access the highest test concentrations that caused dosedependent cytotoxic effects on cells (Swamy and Tan, 2000). After 24 hours of incubation, the test plates were inspected under an inverted microscope. 3-(4,5-dimethyl thiazol-2yl)-2, 5-diphenyl tetrazolium bromide (Sigma) solution of $1 \mathrm{mg} / \mathrm{ml}$ was added to each well of test plates and incubated for an additional 3-4 hours. The assay plate was analyzed by a microplate reader (Tecan, Morrisville, NC) at $570 \mathrm{~nm}$. The concentration required for a $50 \%$ inhibition of viability inhibitory concentration $\left(\mathrm{IC}_{50}\right)$ was determined.

\section{Molecular docking}

Molecular graphics laboratory tools and AutoDock4.2 were used to perform molecular docking. Discovery studio visualizer 4.2 was used to visualize and analyze the molecular docking result. Molecular docking was performed using the Lamarckian genetic algorithm for ligand conformational searching which is used for the docking. A three-dimensional docking grid with the size of $50 \times 50 \times 50 \AA$ and $0.375 \AA$ spacing was used. This grid was centered on the native crystal ligand with the $x, y$, and $z$ coordinates of $16.986,-21.062$, and 11.751, respectively. Docking was performed using PPAR $\gamma$ complexed with rosiglitazone (PDB:1FM6). Validation was performed using native crystal ligand and rosiglitazone to ensure the validity of molecular docking results.

\section{RESULTS AND DISCUSSION}

\section{Phytochemical results}

A new tetramethoxyflavonoid (1), a known tetramethoxyflavonoid (2), and a known steroid (3) were isolated from the leaves extracts of $R$. mimosoides (Fig. 1). The structure of stigmast-4-one-3-ene (3) was identified by spectral data

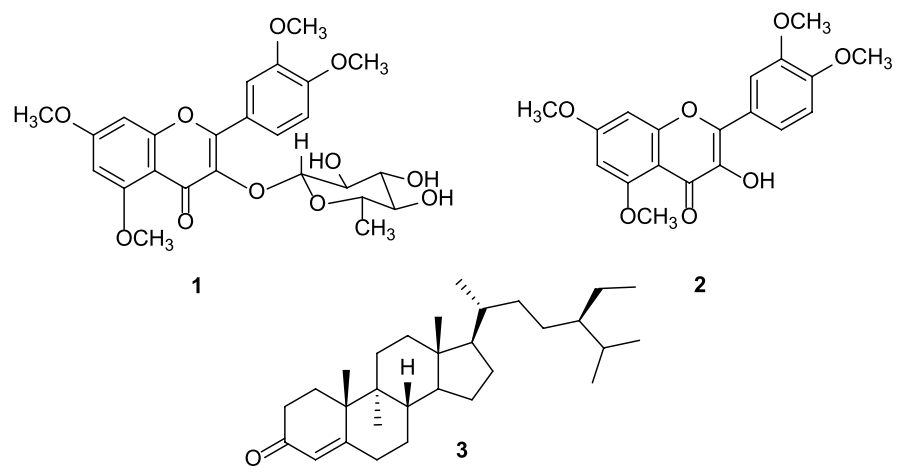

Figure 1. Chemical constituents from R. mimosoides leaves.

analysis and comparison with literature data (Gaspar and das Neves, 1993). Quercetin tetramethyl ether (2) was reported from Sterculia foetida (Anjaneyulu and Murty, 1981); however, the spectral data were not available for comparison. Its spectral data were compared to its synthetic counterpart (Wang et al., 2014). The structure of quercetin tetramethyl ether-3-O- $\beta$-L-rhamnoside (1) was established from the analysis of 1D and 2D and MS spectral data. There is no recent report on the natural occurrence of compound 2. Hence, this paper discusses the characterization of compound $\mathbf{1}$, including full spectroscopic data compound $\mathbf{2}$ for future references. All these structures are presented in Figure 1.

Compound 1 was isolated as colorless crystals. The molecular formula of $\mathrm{C}_{25} \mathrm{H}_{28} \mathrm{O}_{11}$ was generated from LC-MS QTOF with its $[\mathrm{M}+\mathrm{H}]^{+}$at $\mathrm{m} / z 505.2082$ (cald 504.4760 for $\mathrm{C}_{24} \mathrm{H}_{26} \mathrm{O}_{11}$ ). The ${ }^{1} \mathrm{H}$ NMR displayed a 5,7-disubstituted pattern of ring $\mathrm{A}$ with the presence of a pair of meta-coupled signals at $\delta_{\mathrm{H}} 6.43\left(1 \mathrm{H}, d, J_{\mathrm{m}}=2.4 \mathrm{~Hz}, \mathrm{H}-6\right)$ and $\delta_{\mathrm{H}} 6.63\left(1 \mathrm{H}, d, J_{\mathrm{m}}=2.4\right.$ $\mathrm{Hz}, \mathrm{H}-8)$ in addition to two methoxyl signals at $\delta_{\mathrm{H}} 3.94(3 \mathrm{H}, s$, $\left.7-\mathrm{OCH}_{3}\right)$ and $\delta_{\mathrm{H}} 3.95\left(3 \mathrm{H}, s, 5-\mathrm{OCH}_{3}\right)$. The ABX-system of aromatic signals at $\delta_{\mathrm{H}} 7.68\left(1 \mathrm{H}, d d, J_{\mathrm{o}}=8.4 \mathrm{~Hz}, J_{\mathrm{m}}=1.8 \mathrm{~Hz}\right.$, and $\left.\mathrm{H}-6^{\prime}\right), \delta_{\mathrm{H}} 7.28\left(1 \mathrm{H}, d, J_{\mathrm{o}}=8.4 \mathrm{~Hz}, \mathrm{H}-5^{\prime}\right)$, and $\delta_{\mathrm{H}} 7.73\left(1 \mathrm{H}, d, J_{\mathrm{m}}=\right.$ $\left.1.8 \mathrm{~Hz}, \mathrm{H}-2^{\prime}\right)$ together with methoxy proton signals at $\delta_{\mathrm{H}} 3.93(3 \mathrm{H}$, $\left.s, 3^{\prime}-\mathrm{OCH}_{3}\right)$ and $\delta_{\mathrm{H}} 3.82\left(3 \mathrm{H}, s, 4^{\prime}-\mathrm{OCH}_{3}\right)$ indicated the presence of a $3^{\prime}, 4^{\prime}$-disubstituted phenylpropanoid moiety at ring $\mathrm{B}$. The spectral data of the flavanol moiety were in good agreement with spectral data published previously (Wang et al., 2014). A doublet signal at $\delta_{\mathrm{H}} 1.27$ integrated for three protons and several glucoside proton signals were observed in the up field region, suggesting that the glycoside is rhamnose. An anomeric proton was observed at $\delta_{\mathrm{H}} 5.52$ as a doublet with a $J$ value of $1.2 \mathrm{~Hz}$, suggesting that the sugar has $\beta$ configuration (Agrawal, 1992). The APT-NMR spectrum showed 24 carbons, including five methine carbons, 10 quaternary carbons, including the characteristic carbonyl of flavones at $\delta_{\mathrm{C}} 176.4$, and five glycosidic carbons. The anomeric carbon was observed at $\delta_{\mathrm{C}} 100.4$, suggesting that the sugar moiety is linked to aglycone via an $O$-glycosidic linkage. The presence of one primary carbon at $\delta_{\mathrm{C}} 18.4$ confirms the rhamnose's nature of the sugar. The assignment of the methoxy groups at C-5, C-7, C-3', and C-4' was made based on the heteronuclear multiple bond correlation (HMBC) correlations observed between $\mathrm{H}-6\left(\delta_{\mathrm{H}} 6.43\right)$ with C-5 and C-7 and H-2' $\left(\delta_{\mathrm{H}} 7.73\right)$ and $\mathrm{H}-6^{\prime}\left(\delta_{\mathrm{H}} 7.68\right)$ with $\mathrm{C}-3^{\prime}$, respectively. Sugar moiety is assigned at $\mathrm{C}-3$ based on $\mathrm{HMBC}$ cross-peaks observed between $\mathrm{H}-5^{\prime}\left(\delta_{\mathrm{H}} 7.28\right)$ and H-6' $\left(\delta_{\mathrm{H}} 7.68\right)$ 
Table 1. Complete ${ }^{1} \mathrm{H}$ and ${ }^{13} \mathrm{C}$ assignments of compounds $\mathbf{1}$ and $\mathbf{2}$ in $\mathrm{CDCl}_{3}$

\begin{tabular}{|c|c|c|c|c|c|c|}
\hline \multirow{2}{*}{ Position } & \multicolumn{3}{|c|}{ Compound 1} & \multicolumn{3}{|c|}{ Compound 2} \\
\hline & $\delta_{\mathrm{H}}$ & $\boldsymbol{\delta}_{\mathrm{C}}$ & НМВС & $\delta_{\mathrm{H}}$ & $\boldsymbol{\delta}_{\mathrm{C}}$ & HМBC \\
\hline 2 & - & 149.2 & & - & 147.5 & - \\
\hline 3 & - & 154.9 & & $12.86,1 \mathrm{H}, \mathrm{s}$ & 152.6 & - \\
\hline 4 & - & 176.4 & & - & 174.0 & - \\
\hline 5 & - & 162.2 & & - & 163.9 & - \\
\hline 6 & $6.43,1 \mathrm{H}, d, J_{m}=2.4 \mathrm{~Hz}$ & 97.2 & $\mathrm{C}-5, \mathrm{C}-7, \mathrm{C}-8, \mathrm{C}-10$ & $6.28,1 \mathrm{H}, d, J_{m}=2.4 \mathrm{~Hz}$ & 95.8 & C-5, C-7 \\
\hline 7 & - & 166.4 & - & - & 161.0 & - \\
\hline 8 & $6.63,1 \mathrm{H}, d, J_{m}=2.4 \mathrm{~Hz}$ & 93.8 & C-6, C-7, C-9-C10 & $6.43,1 \mathrm{H}, d, J_{m}=2.4 \mathrm{~Hz}$ & 92.5 & $\mathrm{C}-6, \mathrm{C}-9, \mathrm{C}-10$ \\
\hline 9 & - & 160.4 & - & - & 158.7 & - \\
\hline 10 & - & 110.1 & - & - & 109.4 & - \\
\hline $1^{\prime}$ & - & 126.3 & - & - & 123.0 & - \\
\hline $2^{\prime}$ & $7.73,1 \mathrm{H}, d, J_{m}=1.8 \mathrm{~Hz}$ & 113.6 & $\mathrm{C}-2, \mathrm{C}-3^{\prime}, \mathrm{C}-6^{\prime}$ & $7.67,1 \mathrm{H}, d, J_{m}=2.0 \mathrm{~Hz}$ & 111.2 & $\mathrm{C}-2, \mathrm{C}-3, \mathrm{C}-3^{\prime}, \mathrm{C}-4^{\prime}$ \\
\hline $3^{\prime}$ & - & 151.2 & - & - & 140.8 & - \\
\hline $4^{\prime}$ & - & 142.5 & - & - & 146.3 & - \\
\hline $5^{\prime}$ & $7.28,1 \mathrm{H}, d_{o}, J_{o}=8.4 \mathrm{~Hz}$ & 118.0 & $\mathrm{C}-3, \mathrm{C}-1^{\prime}, \mathrm{C}-3^{\prime}$ & $6.97,1 \mathrm{H}, d_{o}, J_{o}=8.4 \mathrm{~Hz}$ & 114.6 & $\mathrm{C}-4^{\prime}, \mathrm{C}-1^{\prime}$ \\
\hline $6^{\prime}$ & $\begin{array}{c}7.68,1 \mathrm{H}, d d, J_{o}=8.4 \mathrm{~Hz}, J_{m} \\
=1.8 \mathrm{~Hz}\end{array}$ & 122.9 & $\mathrm{C}-2^{\prime}, \mathrm{C}-2, \mathrm{C}-3$ & $\begin{array}{c}7.57,1 \mathrm{H}, d d, J_{o}=8.4 \mathrm{~Hz}, J_{m}= \\
2.0 \mathrm{~Hz}\end{array}$ & 122.1 & C-2, C-3, C-4' \\
\hline $1 "$ & $5.52,1 \mathrm{H}, d, J=1.2 \mathrm{~Hz}$ & 100.4 & $\begin{array}{l}\text { C-2", C-5", } \\
\text { C-2 }\end{array}$ & - & - & - \\
\hline $2 "$ & $4.13,1 \mathrm{H}, d d$ & 71.9 & C-4", C-3" & - & - & - \\
\hline $3 "$ & $3.49,1 \mathrm{H}, t$ & 73.9 & C-4", C-5" & - & - & - \\
\hline $4 "$ & $3.94,1 \mathrm{H}, m$ & 72.4 & $\mathrm{C}-3^{\prime \prime}, \mathrm{C}-5^{\prime \prime}$ & - & - & - \\
\hline $5 "$ & $3.76,2 \mathrm{H}, d d$ & 71.0 & $\mathrm{C}-3^{\prime \prime}, \mathrm{C}-4^{\prime \prime}$ & - & - & - \\
\hline $6 "$ & $1.27,3 \mathrm{H}, d$ & 18.4 & $\mathrm{C}-5^{\prime \prime}, \mathrm{C}-3^{\prime \prime}$ & & & \\
\hline $5-\mathrm{OCH}_{3}$ & $3.95,3 \mathrm{H}, s$ & 57.2 & C-5 & $3.84,3 \mathrm{H}, \mathrm{s}$ & 55.8 & C-5 \\
\hline $7-\mathrm{OCH}_{3}$ & $3.94,3 \mathrm{H}, s$ & 166.4 & $\mathrm{C}-7$ & $3.90,3 \mathrm{H}, \mathrm{s}$ & 55.2 & $\mathrm{C}-7$ \\
\hline $3^{\prime}-\mathrm{OCH}_{3}$ & $3.93,3 \mathrm{H}, s$ & 56.9 & $\mathrm{C}-3^{\prime}$ & $3.80,3 \mathrm{H}, \mathrm{s}$ & 60.0 & $\mathrm{C}-3^{\prime}$ \\
\hline $4^{\prime}-\mathrm{OCH}_{3}$ & $3.82,3 \mathrm{H}, s$ & 56.6 & $\mathrm{C}-4^{\prime}$ & $3.91,3 \mathrm{H}, \mathrm{s}$ & 56.2 & $\mathrm{C}-4^{\prime}$ \\
\hline
\end{tabular}

with C-3. Analysis of the spectra data and information found in the literature allowed us to characterize compound $\mathbf{1}$ as quercetin tetramethyl ether-3-O-ß-L-rhamnoside derivative (Table 1).

\section{Biological results}

PPAR $\gamma$ binding activity assay was conducted to access the natural PPAR $\gamma$ ligand present in the compound isolated from the natural resources and binds to PPAR, which then dimerizes with RXR to form a heterodimer which in turn, binds to PPRE in the promoter region, and consequently triggers the transcription of the luciferase gene (Straus and Glass, 2001). The signal produced by the reporter gene was measured by a luminometer. HepG2 cell line was used in this assay because the suppression of PPAR $\gamma$ and $\mathrm{RXR} \alpha$ was found at low levels in the cells to differentiate the transcriptional activation activity of other PPAR isoforms. Thus, expression vectors of PPAR $\gamma$ and RXR $\alpha$ are transfected in this assay system (Han et al., 2002). Compound $\mathbf{2}$ demonstrated the highest binding of PPAR $\gamma$ ligand activity at $0.313 \mu \mathrm{g} / \mathrm{ml}$ with a $2.188 \pm 0.195$-fold increase (Fig. 2). The result of the PPAR $\gamma$ transactivation assay demonstrated that compound $\mathbf{2}$ induced $\operatorname{PPAR} \gamma$ activation when it produced a ratio of luciferase activity higher than rosiglitazone. Polyphenols were known to increase PPAR $\gamma$ expression when administered as part of a high-fat diet in

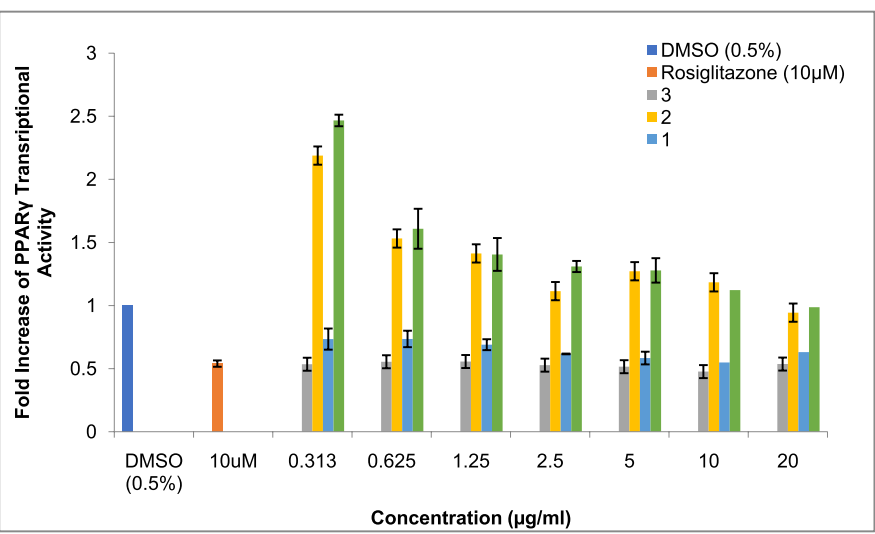

Figure 2. PPAR $\gamma$ transactivation activities of compound $\mathbf{1}$, compound $\mathbf{2}$, and compound $\mathbf{3}$ on HepG 2 cell line. The untreated control $[0.5 \%(v / v)]$ was assigned as 1 .

animal models, particularly in the liver and adipose tissue except for quercetin and catechins (Beekmann et al., 2015). However, compound 2, the methyl ether of quercetin, showed high binding energy with PPAR $\gamma$ in the present study. Compounds $\mathbf{1}$ and $\mathbf{3}$ exhibited similar dose-dependent manner with the best binding 


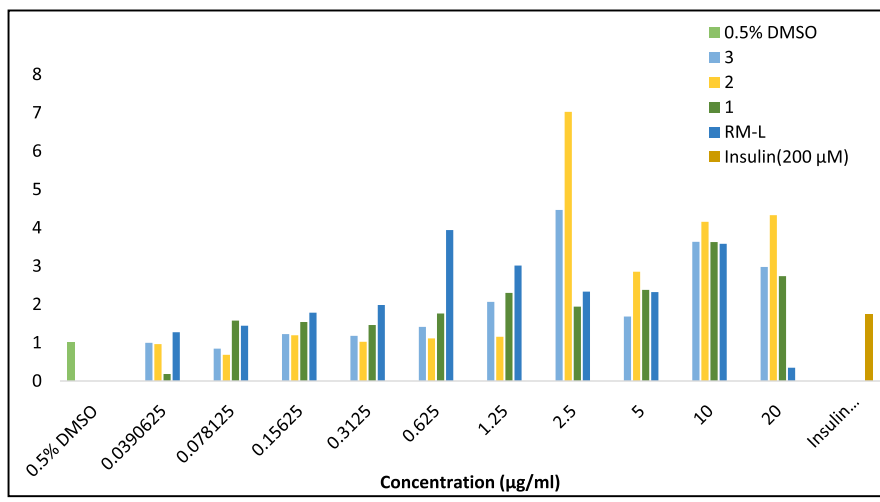

Figure 3. Glucose uptake assay of compounds $\mathbf{1}-\mathbf{3}$ on differentiated $\mathrm{C} 2 \mathrm{C} 12$ cell. Glucose uptake activity in untreated control $[0.5 \%(v / v)$ DMSO] was assigned as 1 .

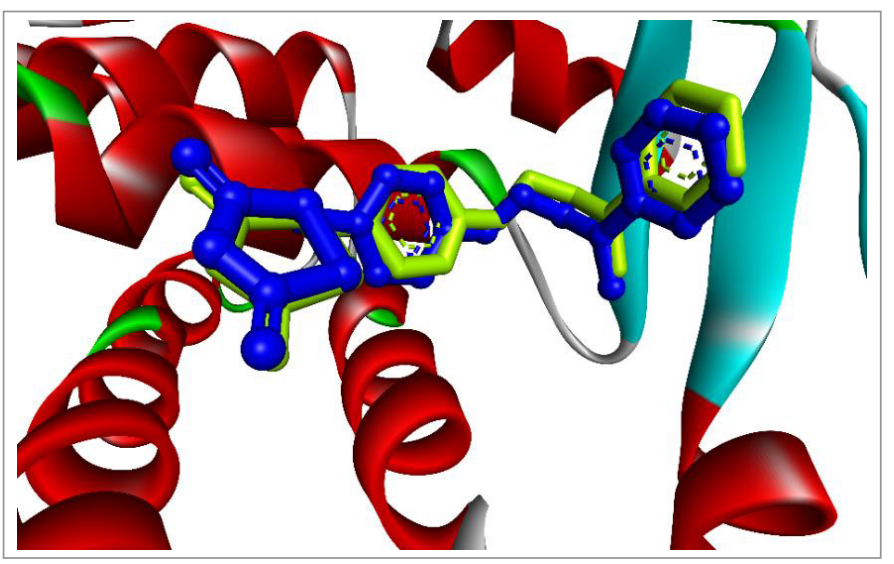

Figure 4. Overlapped structures of native ligand crystal structure of rosiglitazone (blue) and redocked ligand (green).

of PPAR $\gamma$ activity at $0.556 \pm 0.085$-fold increase at $1.25 \mu \mathrm{g} /$ $\mathrm{ml}$ and $0.735 \pm 0.073$-fold increase at $0.625 \mu \mathrm{g} / \mathrm{ml}$, respectively. Compound $\mathbf{1}$, which has a similar aglycone as compound $\mathbf{2}$ except for additional glycoside, showed weaker activity than compound $\mathbf{2}$.

The 2-deoxyglucose uptake assay was designed to evaluate the insulin-like and insulin-sensitizing activity for isolated compounds from $R$. mimosoides. C2C12 myoblast cells were used since skeletal muscle is one of the insulin-responsive tissues responsible for glucose uptake for the maintenance of whole-body glucose homeostasis (Choi et al., 2009). Insulin-induced glucose uptake in adipocytes by binding to insulin receptor proteins within the cell leading to the translocation of glucose transporters 4 to the cell surface (Rathi et al., 2002). Compound 2 exhibited the highest uptake of glucose activity at $2.5 \mu \mathrm{g} / \mathrm{ml}$ with a 7.022 -fold increase (Fig. 3), while compounds $\mathbf{1}$ and $\mathbf{3}$ presented a similar dose-dependent manner and significant difference with minor glucose uptake activities.

The cytotoxicity was conducted to evaluate any toxicity on the cell lines used in this study which were HepG2 cell line and $\mathrm{C} 2 \mathrm{C} 12$ myoblast cell. Initially, the cells were tested with the concentration of compounds starting from 1.56 to $100 \mu \mathrm{g} / \mathrm{ml}$. The ethanolic leaves extract of $R$. mimosoides and compounds 1-3

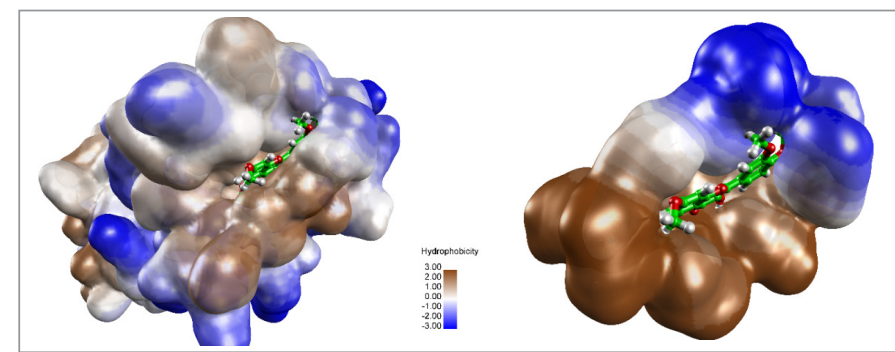

Figure 5. Compound 2 in the binding cavity of PPAR $\gamma$ visualized using hydrophobic surface.

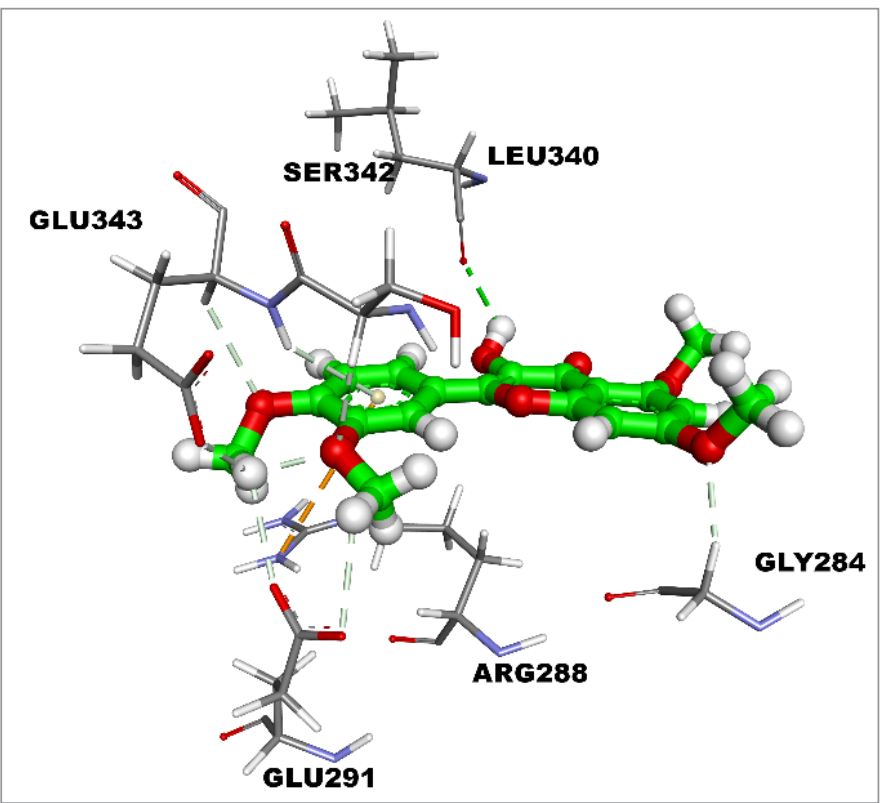

Figure 6. Hydrogen bond interactions of docked ligand in the binding cavity of PPAR $\gamma$.

showed no toxicity on the HepG2 cell line with the $\mathrm{IC}_{50}$ values of more than $100 \mu \mathrm{g} / \mathrm{ml}$.

\section{Molecular docking}

Molecular docking was carried out to identify the plausible binding position of compound 2. Before performing molecular docking of quercetin tetramethyl ether (2) on the target receptor, a validation docking run was done to ensure the reliability and accuracy of the results obtained. Results obtained from the validation run of rosiglitazone suggest that the method developed can reproduce binding position with an acceptable root mean square deviation of $0.54 \AA$ (Fig. 4). The result for plausible binding position of compound $\mathbf{2}$ showed that compound $\mathbf{2}$ is capable of interacting with PPAR $\gamma$ primarily through carbonhydrogen bonds involving ring $\mathrm{B}$.

The chromone moiety can fit in the hydrophobic pocket and interact with various residues within the ligand-binding domain (Fig. 5). Hydroxyl on chromone ring was observed to form a conventional hydrogen bond with the main-chain carbonyl oxygen atom of residue Leu340 at a distance of $2.29 \AA$. The oxygen atom 
of the methoxy on ring A of the chromone ring forms a carbonhydrogen bond with the backbone (Ha) of Gly284 at a distance of $2.34 \AA$. The oxygen atom of the methoxy at the para position of ring $\mathrm{B}$ forms a carbon-hydrogen bond with the backbone (Ha) of important residue Glu343 at a distance of $2.83 \AA$, while the oxygen atom on the other methoxy at the meta-position of ring $\mathrm{B}$ forms a carbon-hydrogen bond with the backbone (Ha) of Ser342 at a distance of $2.45 \AA$. The hydrogen atoms of the methoxy at the para position of ring B can form carbon-hydrogen bonds with the backbone (Oe2) of Glu343 and backbone (Oe1) of Glu291 at a distance of 2.43 and $2.68 \AA$, respectively. On the other hand, the hydrogen atom of the methoxy at the meta-position of ring $B$ formed a carbon-hydrogen bond with the backbone (Oe2) of Glu291 at a distance of $2.62 \AA$ (Fig. 6). The molecular docking result supports the fact that interaction with Arg288 and Glu343 is vital for stable binding between compound 2 and PPAR $\gamma(\mathrm{Li}$ et al., 2008).

\section{CONCLUSION}

Purification of the extract afforded two tetramethoxyflavonoids (1-2) and a triterpene (3). Compound 2 showed the highest PPAR $\gamma$ binding activity and glucose uptake activity. Rourea mimosoides extract and compounds 1-3 showed no cytotoxicity when evaluated using HepG2 cell line. Molecular docking revealed that compound $\mathbf{2}$ is capable of occupying the hydrophobic ligand-binding domain and interacting with crucial residues Arg288 and Glu343 through hydrogen-bonding interactions and thus may have resulted in compound $\mathbf{2}$ acting as an agonist for PPAR $\gamma$. The bioactive compounds identified in this study can be further used as biomarkers for the development of $R$. mimosoides as a botanical drug.

\section{ACKNOWLEDGMENTS}

This work was supported by LESTARI Grant (600-IRMI 5/3/LESTARI (027/2019)) provided by Universiti Teknologi MARA.

\section{AUTHOR CONTRIBUTIONS}

All authors made substantial contributions to conception and design, acquisition of data, or analysis and interpretation of data; took part in drafting the article or revising it critically for important intellectual content; agreed to submit to the current journal; gave final approval of the version to be published; and agree to be accountable for all aspects of the work. All the authors are eligible to be an author as per the international committee of medical journal editors (ICMJE) requirements/guidelines.

\section{CONFLICTS OF INTEREST}

The authors report no financial or any other conflicts of interest in this work.

\section{ETHICAL APPROVALS}

This study does not involve experiments on animals or human subjects.

\section{PUBLISHER'S NOTE}

This journal remains neutral with regard to jurisdictional claims in published institutional affiliation.

\section{REFERENCES}

Agrawal PK. NMR spectroscopy in the structural elucidation of oligosaccharides and glycosides. Phytochemistry, 1992; 31:3307-30.

Alwi SS, Zahari S, Haron A. Cytotoxic effect of 2,6-bis(4Hydroxy-3-Methoxybenzylidene) cyclohexane (BHMC) and curcumin on human liver cancer cells, HepG2. Malays J Med Health Sci, 2019; 15:4450

Anandharajan R, Jaiganesh S, Shankernarayanan NP, Viswakarma RA, Balakrishnan A. In vitro glucose uptake activity of Aegles marmelos and Syzygium cumini by activation of Glut-4, PI3 kinase and PPAR $\gamma$ in L6 myotubes. Phytomedicine, 2006; 13:434-41.

Anjaneyulu ASR, Murty VS. Two rare tetramethyl ethers of quercetin from Sterculia foetida Linn. Indian J Chem, 1981; 20:87-8.

Beekmann K, Rubió L, de Haan LHJ, Actis-Goretta L, van der Burg B, van Bladeren PJ, Rietjens IMCM. The effect of quercetin and kaempferol aglycones and glucuronides on peroxisome proliferatoractivated receptor-gamma (PPAR- $\gamma$ ). Food Funct, 2015; 6:1098-107.

Choi SS, Cha BY, Lee YS, Yonezawa T, Teruya T, Nagai K, Woo JT. Magnolol enhances adipocyte differentiation and glucose uptake in 3T3L1 cells. Life Sci, 2009; 84:908-14.

Christensen KB, Petersen RK, Kristiansen K, Christensen LP. Identification of bioactive compounds from flowers of black elder (Sambucus nigra L.) that activate the human peroxisome proliferatoractivated receptor (PPAR) gamma. Phytother Res, 2010; 24:S129-32.

Gampe RT, Montana VG, Lambert MH, Miller AB, Bledsoe RK, Milburn MV, Kliewer SA, Willson TM, Xu HE. Asymmetry in the PPAR gamma/RXR alpha crystal structure reveals the molecular basis of heterodimerization among nuclear receptors. Mol Cell, 2000; 5:545-55.

Gaspar EMM, das Neves, HJC. Steroidal constituents from mature wheat straw. Phytochemistry, 1993; 34:523-7.

Grosvenor PW, Gothard PK, McWilliam NC, Supriono A, Gray DO. Medicinal plants from Riau Province, Sumatra, Indonesia. Part 1: uses. J Ethnopharmacol 1995; 45:75-95.

Han C, Demetris AJ, Michalopoulos G, Shelhamer JH, Wu, T. 85-kDa cPLA2 plays a critical role in PPAR-mediated gene transcription in human hepatoma cells. Am J Physiol Gastrointest Liver Physiol, 2002; 282:G586-97.

He ZD, Ma CY, Tan GT, Sydara K, Tamez P, Southavong B, Bouamanivong S, Soejarto DD, Pezzuto JM, Fong HHS, Zhang HJ Rourinoside and rouremin, antimalarial constituents from Rourea minor. Phytochemistry, 2006; 67:1378-84.

Janani C, Ranjitha Kumari BD. PPAR gamma gene - a review. Diabetes Metab Syndr, 2015; 9:46-50.

Kalegari, M, Miguel, MD, Dias, JdFG, Lordello, ALL, Lima, CPd, Miyazaki, CMS, Zanin SMW, Verdam MCS, Miguel OG. Phytochemical constituents and preliminary toxicity evaluation of leaves from Rourea induta Planch. (Connaraceae). Braz J Pharm Sci, 2011; 47:635-42.

Laikowski MM, dos Santos PR, Souza DM, Minetto L, Girondi, N, Pires, C, Alano G, Roesch-Ely M, Tasso L, Moura S. Rourea cuspidata chemical composition and hypoglycemic activity. Asian Pac J Trop Biomed, 2017; 7:712-8.

Li Y, Zhang J, Schopfer FJ, Martynowski D, Garcia-Barrio, MT, Kovach, A, Suino-Powell K, Baker PRS, Freeman BA, Chen YE, Xu HE. Molecular recognition of nitrated fatty acids by PPAR $\gamma$. Nat Struct Mol Biol, 2008; 15:865-7.

Mitro N, Gilardi F, Giudici M, Godio C, Scotti E, Crestani M. Site-directed mutagenesis to study the role of specific amino acids in the ligand binding domain of PPARs. Methods Mol Biol, 2013; 952:137-44.

Oliveira PVD, Lemos RPL, Conserva LM. Chemical constituents of Rourea doniana. Rev Bras Farmacogn, 2012; 22:451-4

Pan DS, Wang W, Liu NS, Yang QJ, Zhang K, Zhu JZ, Shan S, Li ZB, Ning ZQ, Huang L, Lu XP. Chiglitazar preferentially regulates gene expression via configuration-restricted binding and phosphorylation inhibition of PPAR $\gamma$. PPAR Res, 2017; 2017:4313561. 
Rangwala SM, Lazar MA. Peroxisome proliferator-activated receptor gamma in diabetes and metabolism. Trends Pharmacol Sci, 2004; 25:331-6.

Rathi SS, Grover JK, Vats V. The effect of Momordica charantia and Mucuna pruriens in experimental diabetes and their effect on key metabolic enzymes involved in carbohydrate metabolism. Phytother Res, $2002 ; 16: 236-43$

Straus DS, Glass CK. Cyclopentenone prostaglandins: New insights on biological activities and cellular targets. Med Res Rev, 2001; $21: 185-210$.

Swamy SMK, Tan BKH.Cytotoxic and immunopotentiating effects of ethanolic extract of Nigella sativa L. seeds. J Ethnopharmacol, 2000; 70:1-7.

Tan SY, Koh CY, Siow HJM, Li T, Wong HF, Heyzer A, Tan HTW. 100 common vascular plants of the nee soon swamp forest, Singapore. Raffles Museum of Biodiversity Research, Singapore, Singapore, 2013.

Tedong L, Madiraju P, Martineau LC, Vallerand D, Arnason JT, Desire DDP, Lavoie L, Kamtchouing P, Haddad PS. Hydro-ethanolic extract of cashew tree (Anacardium occidentale) nut and its principal compound, anacardic acid, stimulate glucose uptake in $\mathrm{C} 2 \mathrm{C} 12$ muscle cells. Mol Nutr Food Res, 2010; 54:1753-62.

Wang Z, Yang L, Cui S, Liang Y, Zhang X. Synthesis and anti-hypertensive effects of the twin drug of nicotinic acid and quercetin tetramethyl ether. Molecules, 2014; 19:4791-801.

Zhang KM, Jiang JQ, Kong L. Chemical constituents from Rourea microphylla. Chin J Nat Med, 2008; 6:345-7.

\section{How to cite this article:}

Osman CP, Zomat NA, Zahari Z, Imran S, Adenan MI. Isolation, peroxisome proliferator-activated receptor-gamma transcription, glucose uptake, and molecular docking of tetramethoxyflavonoids from the leaves of Rourea mimosoides (Vahl) Planch. J Appl Pharm Sci, 2021; 11(08):010-016. 